\title{
Electrogenic colonic ion transport in Hirschsprung's disease: reduced secretion to the neural secretagogues acetylcholine and iloprost
}

\author{
S P Hardy, P M Smith, R Bayston, L Spitz
}

\begin{abstract}
The effects of the abnormal innervation in Hirschsprung's disease on colonic ion transport were examined in vitro using Ussing chambers. The response of the mucosal/submucosal preparations to different secretagogues were investigated in aganglionic and ganglionic rectosigmoid and transverse colon from children with Hirschsprung's disease and compared with normally innervated colon from children with anorectal anomalies. Basal values were similar in aganglionic and ganglionic rectosigmoid colon. Neurally mediated secretion with iloprost $\left(10^{-6} \mathrm{M}\right)$ and acetylcholine (900 and $9 \mu M$ ) was considerably reduced in aganglionic colon compared with normally innervated ganglionic colon. The ganglionic colon proximal to the aganglionic colon also had a reduced response to acetylcholine despite a normal acetylcholinesterase staining pattern. The responses to Escherichia coli STa enterotoxin (50 MU/ml) and isobutylmethylxanthine $\left(10^{-3} \mathrm{M}\right)$ were similar in ganglionic and aganglionic colon. The response to STa enterotoxin was not changed by the nerve blocking agent tetrodotoxin $\left(10^{-6} \mathrm{M}\right)$. The data show that colonocytes from aganglionic colon are capable of a normal secretory response if stimulated directly by cAMP or cGMP acting secretagogues but secretion in response to neurally mediated secretagogues is impaired. The hypertrophied acetylcholinesterase positive nerve fibres that infiltrate the aganglionic colon are likely to contribute to the reduced secretion to acetylcholine.

(Gut 1993; 34: 1405-1411)
\end{abstract}

Department of Paediatric Surgery, Institute of Child Health, London S P Hardy

L Spitz

Department of Clinical Dental Sciences,

University of Liverpool,

Liverpool

P M Smith

Division of Cell and

Molecular Biology,

Institute of Child Health,

London

$R$ Bayston

Correspondence to:

Dr S P Hardy, Department of

Cell Biology, AFRC Institute

of Animal Physiology and

Genetics Research,

Babraham, Cambridge

CB2 4AT.

Accepted for publication

9 February 1993
Hirschsprung's disease (HD) is characterised by spastic constriction of the affected colon associated with a variable length of aganglionosis in the distal colon and proliferation of extrinsic nerve fibres. ${ }^{1}$ The exact mechanisms responsible for the abnormal smooth muscle function in the affected colon remains unknown but amply show the importance of the enteric nervous system in regulating colonic function.

By contrast with the substantial body of research on the smooth muscle changes in HD, the role of the enteric nervous system on human colonic ion transport either under normal conditions or in various disease states remains unexplored. Heath $e a^{2} l^{2}$ examined the absorptive function of the rectum in vivo in children with HD and showed greater absorption of sodium and chloride ions and higher rectal potential difference compared with control children.

To determine the effect of the neural abnor- malities in HD on colonic ion transport, the basal electrical properties and response to neurally mediated secretagogues (iloprost), neurotransmitters (acetylcholine and carbachol), and luminally active secretagogues were examined in (a) aganglionic and ganglionic rectosigmoid colon and (b) ganglionic transverse colon. A preliminary report of this study has been communicated to the Physiological Society. ${ }^{3}$

\section{Methods}

\section{TISSUE SPECIMENS}

Tissue specimens were obtained from children having corrective surgery for $\mathrm{HD}$ (mean age $6 \cdot 1$ months, range 3-11). The normally innervated 'control' tissues were obtained from children with anorectal anomalies (mean age 18.9 months, range 1-120). All transverse colon specimens were taken from left (proximal transverse) colostomy closures. Children with other intestinal neuropathies were excluded. All specimens were obtained from scheduled operations (approval obtained from the Hospital Ethical Committee) from children with normal electrolyte status.

Most of the patients received $0.2 \mathrm{mg}$ atropine as part of the inductive anaesthetic course. All children received endotracheal anaesthesia with halothane, nitrous oxide, and oxygen together with narcotic mediated analgesia with fentanyl or morphine and bipivucaine (peripheral or epidural).

The duration of ischaemia due to clamping of the main tissue blood supply or dissection was minimised and usually less than 40 minutes. Collateral blood supply was not disrupted while dissection took place. Tissues were collected in theatre in ice chilled oxygenated NaCl-Ringer's solution and transported immediately to the laboratory. The tissue segments were opened longitudinally and the luminal surface rinsed in $\mathrm{NaCl}$-Ringer's solution. The tissues were pinned out on wax, mucosal surface down, and stripped free of the outer layers of muscle using microdissection scissors at $\times 50$ magnification. Care was taken to remove as little submucosal tissue as possible. The tissues were bathed in oxygenated $\mathrm{NaCl}$-Ringer's solution during dissection, which took 10 to 15 minutes. The dissected outer muscle layers together with mucosa/submucosa adjacent to the tissue used in the Ussing chambers were fixed for histological analysis.

The preparations of mucosa/submucosa were mounted in Perspex open topped Ussing type chambers against rubber ' $O$ rings' to minimise edge damage. The exposed tissue area was $0.9 \mathrm{~cm}^{2}(0 \cdot 17 \times 0.06 \mathrm{~cm}$ rectangle $)$. Tissue sur- 
faces were bathed with $\mathrm{NaCl}$-Ringer's solution containing (in mmol/l) NaCl 113; KCl $4.5 ; \mathrm{MgCl}_{2}$ $1 \cdot 0 ; \mathrm{Na}_{2} \mathrm{HPO}_{4} 0 \cdot 2 ; \mathrm{NaHCO}_{3} 25 ; \mathrm{CaCl}_{2} 1 \cdot 25$, and glucose $10 \cdot 0$. Each chamber was oxygenated and stirred directly by bubbling with $5 \% \mathrm{CO}_{2}$ in oxygen. The chamber was kept at $37^{\circ} \mathrm{C}$ by a heated water jacket.

\section{ELECTRICAL MEASUREMENTS}

The electrical indices were recorded using standard procedures by a computer based voltage clamp modified from that described by Naftalin and Smith. ${ }^{4}$ Experiments were carried out under open circuit conditions. The short circuit current values were calculated from the potential difference and tissues resistance using Ohm's law and recorded as $\mu \mathrm{A} / \mathrm{cm}^{2}$.

\section{DRUGS}

Acetylcholine, carbachol, and 3-isobutyl 1-methylxanthine (IBMX) were prepared in $\mathrm{NaCl}$-Ringer's solution. $E$ coli STa enterotoxin was dissolved in $0.9 \%$ phosphate buffered saline and stored as a stock of $1000 \mathrm{MU} / \mathrm{ml}$ at $-27^{\circ} \mathrm{C}$ in $0.5 \mathrm{ml}$ volumes. Tetrodotoxin was dissolved in 5 $\mathrm{mM}$ disodium citrate and stored at $10^{-4} \mathrm{M}$ concentration at $4^{\circ} \mathrm{C}$, protected from the light. The efficacy and stability of the tetrodotoxin was confirmed periodically by studies carried out on unstripped rat distal colon in Ussing chamber preparation. Tetrodotoxin $\left(10^{-6} \mathrm{M}\right)$ applied to the serosal (but not the mucosal) bathing solution caused an immediate drop of about $88 \%$ of the transepithelial potential difference and short circuit current without any significant change in transepithelial resistance and abolished the rises in potential difference and short circuit current seen after neural stimulation by electrical field stimulation at $10 \mathrm{~Hz}, 5 \mathrm{msec}$ pulse width, $1-5 \mathrm{~V}$ for 30 seconds.

\section{EXPERIMENTAL PROTOCOL}

After mounting, tissues were allowed to equilibrate to a stable baseline ( 25 to 90 minutes). Five minutes before addition of the agonist the electrical sampling frequency was increased to 10 to 30 seconds. After exposure to agonists both mucosal and serosal bathing solutions were changed with at least three washes of oxygenated prewarmed Ringer's solution and left for a period of 20 to 45 minutes in which to reequilibrate before addition of further agonists. Changes in the potential difference, short circuit current, and transepithelial resistance after agonist were compared with the mean of the baseline taken over the five minutes before the addition of the agonist. Tissues maintained stable electrical indices for up to five hours after which they would usually show a steady decline in transepithelial resistance and potential difference. Experiments were usually stopped after four hours.

\section{HISTOLOGY}

Tissues removed from children with HD were separated into the different groups after histo- logical examination for the presence or absence of ganglion cells, which was performed after the Ussing chamber experiments. Tissues were pinned out on silicone rubber and fixed in $4 \%$ (wt/vol) paraformaldehyde in phosphate buffered saline $(\mathrm{pH} 7 \cdot 3)$ at $4^{\circ} \mathrm{C}$ for 90 minutes. Tissues were then washed at room temperature for 15 to 30 minutes in phosphate buffered saline and stored at $4{ }^{\circ} \mathrm{C}$ in $7 \%$ sucrose $-0.1 \%$ sodium azide - phosphate buffered saline until processed. Tissues were prepared in OCT (BDH) and snap frozen in liquid nitrogen chilled isopentane. Ten $\mu \mathrm{m}$ transverse sections were then cut in a cryostat. Five to nine sections taken every $100 \mu \mathrm{m}$, collected onto gelatin subbed slides, and stored at $-27^{\circ} \mathrm{C}$.

\section{NADH diaphorase activity}

The presence or absence of neurons within the submucosal and myenteric plexus of the tissues was confirmed by staining for NADH diaphorase activity using the method of Hoyle and Burnstock. ${ }^{5}$ Slides were incubated at $37^{\circ} \mathrm{C}$ in phosphate buffered saline containing $1 \mathrm{mM}$ NADH (Fluka) and nitroblue tetrazolium $(0.6 \mathrm{mM})$ for 30 to 45 minutes. The staining intensity was controlled visually.

\section{Acetylcholinesterase activity}

Acetylcholinesterase activity was detected using a method based on that of Karnovsky and Roots ${ }^{6}$ in the presence of the non-specific acetylcholinesterase inhibitor iso-OMPA and stain intensified with $0 \cdot 1 \%$ silver nitrate (60 seconds). The slides were lightly counterstained with Carazzi's haematoxylin (10 seconds).

\section{CHEMICALS}

Iloprost was generously donated by Schering (W Sussex, England). Most other chemicals, unless otherwise stated, were obtained from Sigma (Poole, UK).

\section{STATISTICS}

Results are given as the mean (one SEM). Where sufficient tissue was available to test more than one tissue from the same child in the chambers, the results were averaged and considered as one tissue. Statistical significance was tested using the non-parametric Kruskal-Wallis analysis of variance and Kolgomorov-Smirnoff 2 sample test. Significance was taken at $\mathrm{p}<0.05$.

\section{Results}

BASAL ELECTRICAL PROPERTIES

Table I summarises the basal electrical measurements in $\mathrm{NaCl}$-Ringer's solution after equilibration (usually 60 minutes, range 25 to 90 minutes). The values obtained from the aganglionic rectosigmoid colon were not significantly different from the ganglionic rectosigmoid colon either from patients with HD or from the normally innervated controls.

No differences were found in the values from 
TABLE I Basal electrical properties of human paediatric rectosigmoid and transverse colon

\begin{tabular}{lllll}
\hline & $N o$ & $V t(\mathrm{mV})$ & $I s c\left(\mu \mathrm{A} / \mathrm{cm}^{2}\right)$ & $\operatorname{Rt}\left(\Omega \cdot \mathrm{cm}^{2}\right)$ \\
\hline Rectosigmoid colon & & & & \\
Aganglionic (HD) & 26 & $11 \cdot 7(1 \cdot 5)$ & $-138 \cdot 4(17 \cdot 0)$ & $91 \cdot 6(7 \cdot 5)$ \\
Ganglionic (ARA) & 23 & $10 \cdot 3(1 \cdot 4)$ & $-119 \cdot 9(15 \cdot 5)$ & $99 \cdot 4(7 \cdot 9)$ \\
Ganglionic (HD) & 14 & $12 \cdot 0(1 \cdot 8)$ & $-120 \cdot 6(14 \cdot 1)$ & $96 \cdot 3(7 \cdot 5)$ \\
Transverse colon & 15 & $12 \cdot 3(2 \cdot 0)$ & $-109 \cdot 5(14 \cdot 4)$ & $113 \cdot 5(15 \cdot 1)$ \\
Ganglionic (HD) & 13 & $10 \cdot 0(1 \cdot 9)$ & $-91 \cdot 2(15 \cdot 9)$ & $118 \cdot 4(12 \cdot 8)$ \\
Ganglionic (ARA) & &
\end{tabular}

Results are given as mean (SEM). $\mathrm{HD}=$ Hirschsprung's disease; $\mathrm{ARA}=$ anorectal anomalies; $\mathrm{V}=$ transepithelial potential difference (serosal side positive); Isc=calculated short circuit current; $\mathrm{Vt}=$ transepithelial potential difference (serosal side posit
$\mathrm{Rt}=$ transepithelial resistance; $\mathrm{No}=$ number of children.

No significant differences were found between the five groups of tissues.

the ganglionic transverse colon between children with HD and those with anorectal anomalies. The values from the transverse colon in children with HD and the controls were not significantly different from those of the rectosigmoid colon. No relation was found between the age of the patient and the basal electrical properties. The age ranges of the five groups were comparable.

The addition of $90 \mu \mathrm{M}$ ouabain (BDH) to the serosal bathing solution resulted in almost complete abolition of the potential difference and short circuit current (potential difference $=<0.5$ $\mathrm{mV}$ ) in ganglionic colon (five tissues from four children: three transverse, two rectosigmoid colon).

\section{NEURALLY MEDIATED SECRETION}

To examine the effect of neurally mediated secretion of the aganglionic colon iloprost, a prostacyclin $\mathrm{PGI}_{2}$ analogue, was chosen. Iloprost has been shown to act through the submucosal neural tissues, and not directly on the colonocyte, to cause chloride secretion in rat distal colon. ${ }^{7}$ Iloprost $\left(10^{-6} \mathrm{M}\right)$ added to the serosal bathing solution of the normally innervated control rectosigmoid colon (tissues from seven children, mean age: 4.8 months) resulted in an appreciable rise in tissue potential difference $(+6.7(1.5) \mathrm{mV})$ and short circuit current (102.6 (15.9) $\left.\mu \mathrm{A} / \mathrm{cm}^{2}\right)$ together with a fall in tissue resistance $\left(-17 \cdot 7(5 \cdot 6) \Omega \cdot \mathrm{cm}^{2}\right)$. Figure 1 shows the time course of action.

The addition of tetrodotoxin $\left(10^{-6} \mathrm{M}\right)$ before the serosal bathing solution completely prevented any increase in potential difference or short circuit current $(n=3$; data not shown). The

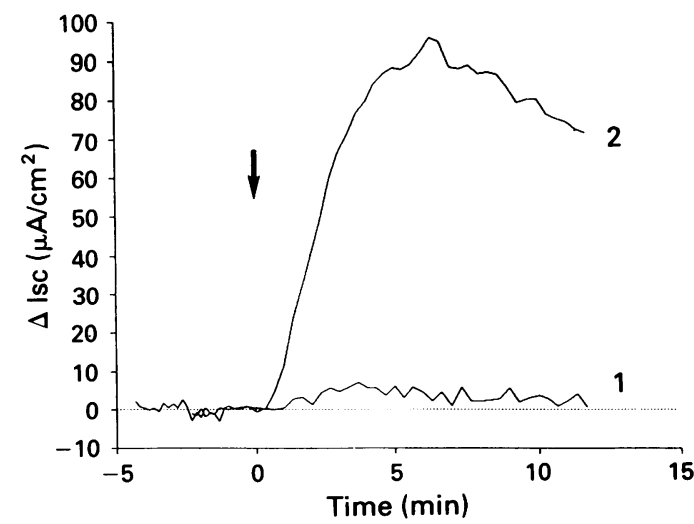

Figure 1: Effect of iloprost $\left(10^{-6} \mathrm{M}\right)$ added to the serosal bathing solution at time 0 (arrow) on the short circuit current (Isc) of (1) aganglionic rectosigmoid colon (four month boy) and (2) ganglionic rectosigmoid colon (three month boy).

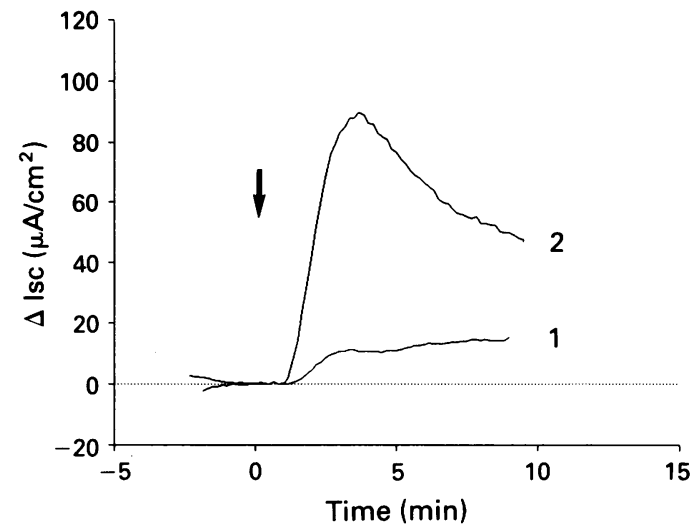

Figure 2: Effect of acetylcholine $(900 \mu M)$ added to the serosal bathing solution at time $O$ (arrow) on the short circuit current (Isc) of (1) aganglionic rectosigmoid colon (six month boy) and (2) ganglionic rectosigmoid colon (two month boy).

addition of tetrodotoxin, once the secretion had stabilised at maximum values after the addition of iloprost, reversed the increase in potential difference, short circuit current, and transepithelial resistance. The addition of iloprost to the mucosal bathing solution failed to result in any change in electrical properties.

In contrast, addition of iloprost to the serosal bathing solution of aganglionic rectosigmoid colon resulted in no significant change in potential difference $(+0.4(0 \cdot 1) \mathrm{mV})$ or short circuit current $\left(+7 \cdot 8(1.6) \mu \mathrm{A} / \mathrm{cm}^{2}\right)$ in tissues from eight children $(\mathrm{p}<0.001 v$ control ganglionic colon). The fall in transepithelial resistance $(-3.8(1 \cdot 2)$ $\Omega \cdot \mathrm{cm}^{2}$ ) did not reach statistical significance compared with the ganglionic control tissues $(-6 \cdot 0$ $\left.(2 \cdot 6) \Omega \cdot c,{ }^{2}\right)$. Figure 1 shows a typical trace together with that of the control ganglionic colon.

\section{CHOLINERGIC AGONISTS}

The effect of direct cholinergic neurotransmitter action on the colonocyte was examined. Addition

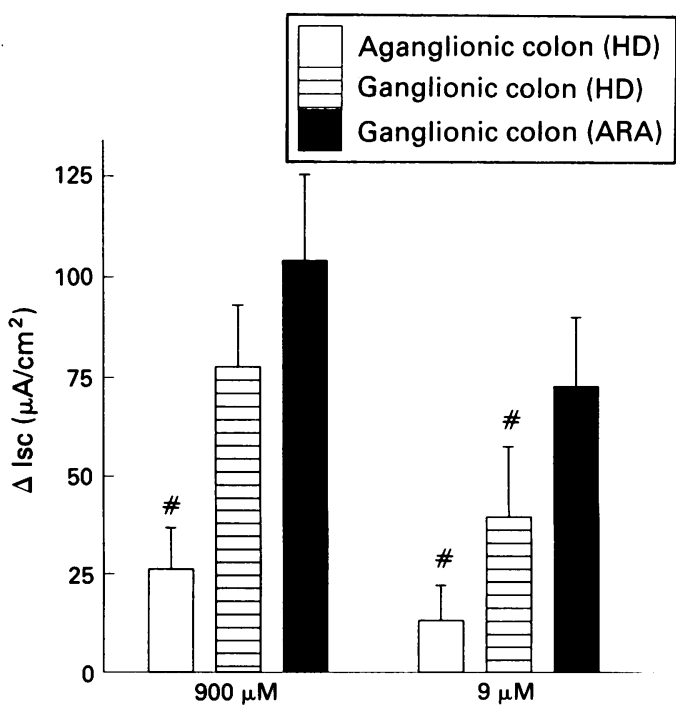

Figure 3: Changes in short circuit current (Isc) (Mean (SEM)) to acetylcholine and carbachol of aganglionic colon $(n=8$ to 12 per agonist) and ganglionic colon ( $n=6$ to $12 \mathrm{per}$ agonist). $\# p=<0.05 \mathrm{v}$ ganglionic control colon.

agonist $)$. $H D=<$ irchsprung's disease, $A R A=$ anorectal anomalies.
$H D$ 
of acetylcholine (900 and $9 \mu \mathrm{M}$ ) to the serosal bathing solution of the control ganglionic rectosigmoid colon gave transient increases in potential difference and short circuit current coupled with a fall in transepithelial resistance. Figure 2 shows the time course of action of $900 \mu \mathrm{M}$ acetylcholine. Maximum responses were obtained at about two $(900 \mu \mathrm{M})$ and about five minutes $(9 \mu \mathrm{M})$ after addition to the serosal bathing solution.

By contrast with ganglionic colon, aganglionic colon gave either a small or absent response to serosal acetylcholine compared with control ganglionic tissues (data summarised in Fig 3). Figure 2 shows a typical trace of the response of aganglionic rectosigmoid colon to high concentrations of acetylcholine $(900 \mu \mathrm{M})$.

Subsequent experiments using the acetylcholinesterase resistant acetylcholine analogue carbachol $(9 \mu \mathrm{M})$ to the serosal bathing solution of control ganglionic rectosigmoid colon resulted in a transient rise in potential difference and short circuit current $(+4.6(0.9) \mathrm{mV} ;+62.5$ (14.5) $\mu \mathrm{A} / \mathrm{cm}^{2}$ respectively; tissues from eight children).

The response of aganglionic rectosigmoid colon to carbachol showed considerable variation (median increase in short circuit current: $+\mathbf{1 6} \cdot 2$, range $0-135 \cdot 5 \mu \mathrm{A} / \mathrm{cm}^{2}$ ). The mean response was not significantly different from that of the control ganglionic tissues using non-parametric analysis $(p=0.06)$. Two broad patterns of response to carbachol, however, could be seen. Seven of the total 14 aganglionic tissues gave increases of less than $10 \mu \mathrm{A} / \mathrm{cm}^{2}$ (mean increase of $3.1(1.4) \mu \mathrm{A}$ $\mathrm{cm}^{2} ; \mathrm{p}=0.001 v$ control tissues). The other seven tissues responded to carbachol with a mean increase of $66.4(15.9) \mu \mathrm{A} / \mathrm{cm}^{2}(\mathrm{p}>0.05 v$ control tissues).

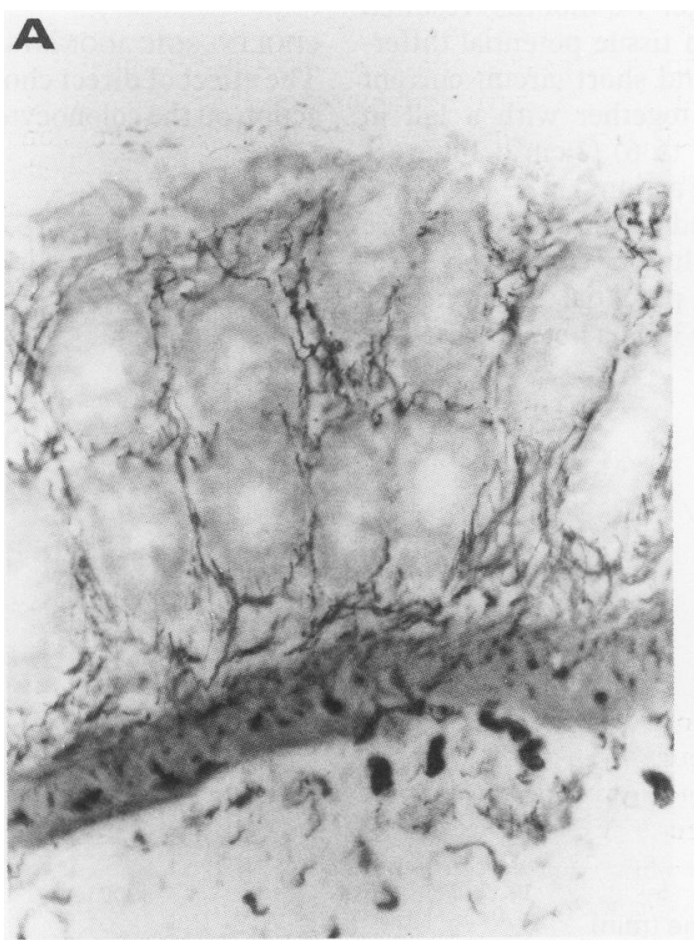

ACETYLCHOLINESTERASE STAINING PATTERN

The extent of the acetylcholinesterase activity within the submucosa and mucosal tissues was examined histochemically. In ganglionic colon from children with anorectal anomalies acetylcholinesterase staining was present in the ganglia of the myenteric and submucosa plexus with occasional nerve fibres in the submucosa and lamina propria. In contrast, aganglionic tissues from children with HD showed dense staining of large acetylcholinesterase positive nerve fibres in the submucosa, lamina propria, and particularly the muscularis mucosa (Fig 4).

The abundant acetylcholinesterase activity released by the hypertrophied nerve fibres is likely to contribute to the impaired response to acetylcholine.

\section{E COLI STA ENTEROTOXIN}

To examine the secretory response of the colonocytes to secretagogues added to the luminal bathing solution, tissues were challenged with $50 \mathrm{MU} / \mathrm{ml} E$ coli STa enterotoxin. The binding of STa enterotoxin to specific receptors on human colonic mucosa has been shown to increase mucosal guanylate cyclase concentrations $^{8}$ and to increase cGMP in intestinal cell lines.

Control ganglionic colon (tissues from nine children) showed a prompt increase in potential difference $(+4.7(1.5) \mathrm{mV})$ and short circuit current $\left(+39 \cdot 0(6 \cdot 4) \mu \mathrm{A} / \mathrm{cm}^{2}\right.$, Fig 5A). The tissue resistance showed an initial increase in of 6.5 (2.6) $\Omega \cdot \mathrm{cm}^{2}$ before a subsequent fall of $-9 \cdot 15$ (4.6) $\Omega \cdot \mathrm{cm}^{2}$ (Fig 5B shows a typical trace). Aganglionic colon gave similar responses to STa enterotoxin in potential difference $(+3 \cdot 2(1 \cdot 1)$ $\mathrm{mV})$, short circuit current $\left(+33 \cdot 6(11 \cdot 8) \mu \mathrm{A} / \mathrm{cm}^{2}\right)$

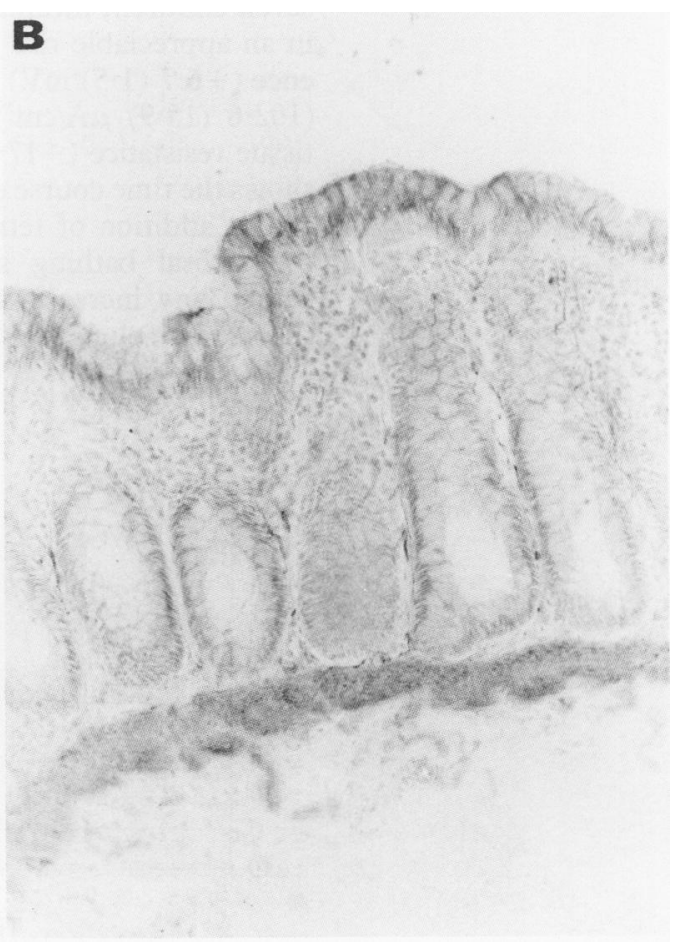

Figure 4: (A) Photomicrograph of rectosigmoid colon from a child with Hirschsprung's disease (three month girl) showing increased acetylcholinesterase activity in the hypertrophied nerve bundles in the submucosa, muscularis mucosa, and lamina propria compared with $(B)$ ganglionic tissue from a child with anorectal anomaly (eight month boy) showing minimal distribution of acetylcholinesterase activity (original magnification $\times 200$ ). 

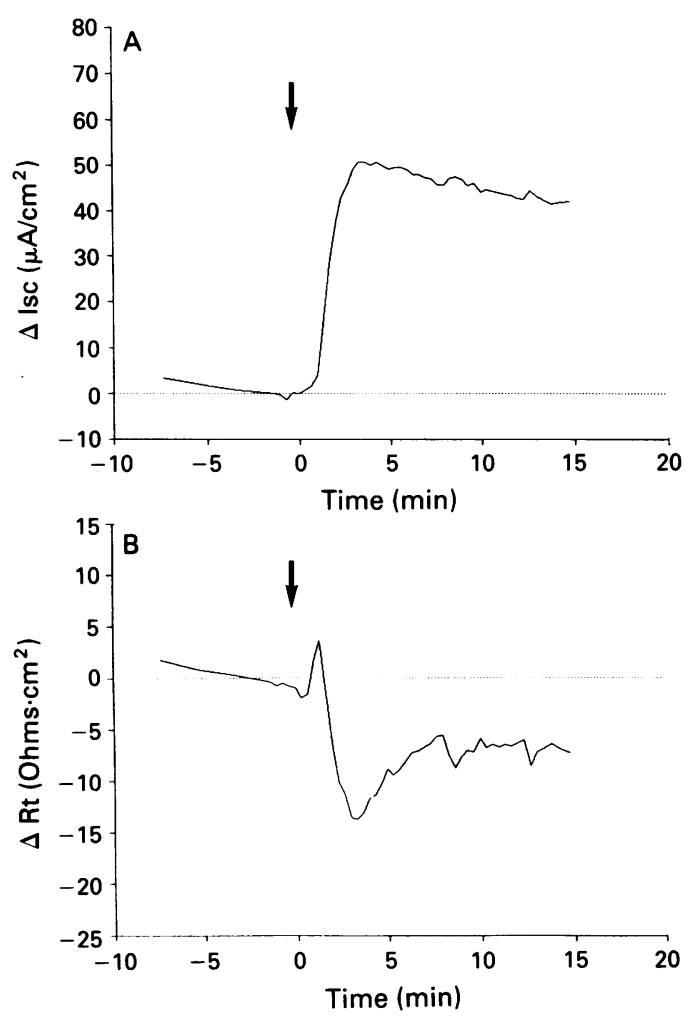

Figure 5: Response to E coli STa enterotoxin (50 MU/ml) added to the mucosal bathing solution at time 0 on the $(A)$ short circuit current (Isc) and (B) transepithelial resistance (RT) of ganglionic transverse colon (four month girl) from a child with imperforate anus.

and transepithelial resistance (an initial increase of $+4 \cdot 6(1 \cdot 7) \Omega \cdot \mathrm{cm}^{2}$ followed by a fall of $-6 \cdot 3$ $(1 \cdot 2) \Omega \cdot \mathrm{cm}^{2}$; tissues from four children) which were not significantly different from the increases in the control ganglionic colon. The increases in potential difference and short circuit current were reversible on washing out of the bathing solutions. Repeat challenge with STa enterotoxin 45 to 60 minutes later in the presence of serosal tetrodotoxin $\left(10^{-6} \mathrm{M}\right.$ gave similar increases. The increase in short circuit current to STa enterotoxin in the presence of tetrodotoxin was not significantly different between the aganglionic and ganglionic colon (increase in short circuit current (SEM): $+25 \cdot 9(4 \cdot 3) \mu \mathrm{A} / \mathrm{cm}^{2}$ (aganglionic colon, $\mathrm{n}=4$ ) $v 37 \cdot 0(8 \cdot 7) \mu \mathrm{A} / \mathrm{cm}^{2}$ (ganglionic colon, $n=4$ ). The initial rise in transepithelial resistance was unaffected by the presence of tetrodotoxin. No correlation was found between age of the patient and the response to STa.

\section{RESPONSE TO ISOBUTYLMETHYLXANTHINE}

Tissues were challenged with 3-isobutyl-1methylxanthine (IBMX $1 \mathrm{mM}$ ) in the mucosal bathing solution to stimulate secretion by cell cyclic nucleotides through inhibition of phosphodiesterase activity and activation of adenylate cyclase activity. No differences were seen in the responses of aganglionic colon (increase in potential difference: $11.9(0.9) \mathrm{mV}$; short circuit current: $+157.4(4.3) \mu \mathrm{A} / \mathrm{cm}^{2}$; fall in transepithelial resistance: $-21 \cdot 0(4 \cdot 7) \Omega \cdot \mathrm{cm}^{2}$; tissues from three children) and control ganglionic colon (potential difference: $+10 \cdot 2(1 \cdot 2) \mathrm{mV}$; short circuit current: $+170.7(12.6) \mu \mathrm{A} / \mathrm{cm}^{2}$; fall in transepithelial resistance: $-26 \cdot 0(6 \cdot 0) \Omega \cdot \mathrm{cm}^{2}$; tissues from three children).

These data suggest that, if stimulated directly, the colonocytes in aganglionic colon have an unimpaired secretory capability.

SECRETION IN PROXIMAL GANGLIONIC COLON FROM CHILDREN WITH HIRSCHSPRUNG'S DISEASE To determine whether the reduced secretory response to iloprost and acetylcholine was confined to the aganglionic segment or extended proximally into ganglionic colon we examined the basal and secretory responses in the ganglionic rectosigmoid proximal to the aganglionic region. In addition, the basal and secretory responses of the proximal right transverse colon in children with $\mathrm{HD}$ against children with anorectal anomalies were compared.

\section{Ganglionic rectosigmoid colon from children with $H D$}

The basal electrical properties of the ganglionic rectosigmoid colon from children with HD (mean age 14.7 months, range 3 to 48 ) were comparable with the ganglionic control tissues (see Table I).

The response of the ganglionic rectosigmoid colon to neural activation by $10^{-6} \mathrm{M}$ iloprost was not significantly different from the control ganglionic colon described above (increase in short circuit current (SEM): $+82 \cdot 1(8 \cdot 9) \mu \mathrm{A} / \mathrm{cm}^{2}(\mathrm{HD}$, $\mathrm{n}=8) v 94 \cdot 4(14 \cdot 6) \mu \mathrm{A} / \mathrm{cm}^{2}$ (control, $\mathrm{n}=7$ ).

The response of the proximal ganglionic rectosigmoid colon from children with HD to $9 \mu \mathrm{M}$ acetylcholine was significantly reduced compared with the control ganglionic colon (increase in short circuit current (SEM): +26.5 (9.1) (ganglionic $\mathrm{HD}, \mathrm{n}=14) v+76 \cdot 2(14 \cdot 6) \mu \mathrm{A} / \mathrm{cm}^{2}$ (control colon, $\mathrm{n}=12 ; \mathrm{p}<0.01$ ). Ganglionic colon proximal to the aganglionic zone had acetylcholinesterase staining patterns comparable with the control tissues. No apparent increase in acetylcholinesterase activity within the muscularis mucosa was seen. The response to carbachol although showing wide variability similar to that seen in the aganglionic tissues (increase in short circuit current: $+106 \cdot 5(36 \cdot 5)$ $\mu \mathrm{A} / \mathrm{cm}^{2}$, tissues from four children) was not significantly different from the ganglionic control colon.

The ganglionic rectosigmoid colon from children with HD gave increases in potential difference and short circuit current to IBMX and STa enterotoxin that were not significantly different from the values obtained from the control ganglionic colon described above (mean increase in short circuit current (SEM) to $50 \mathrm{MU} / \mathrm{ml} \mathrm{STa}$ enterotoxin: $+45 \cdot 1(8.9)$; tissues from five children; to $1 \mathrm{mM} \mathrm{IBMX:}+232.9(17.4) \mu \mathrm{A} /$ $\mathrm{cm}^{2}$; tissues from three children).

\section{Ganglionic transverse colon}

Table I gives the basal electrical values of the proximal transverse colon in children with HD (mean age 16 months, range 3 to 45) and children with anorectal anomalies (mean age $17 \cdot 8$ months, 
TABLE II Increase in Isc $\left(\mu A / \mathrm{cm}^{2}\right)$ across the transverse colonic mucosa from children with Hirschsprung's disease or anorectal anomalies

\begin{tabular}{lll}
\hline Secretagogue & $\begin{array}{l}\text { Hirschsprung's } \\
\text { disease }\end{array}$ & $\begin{array}{l}\text { Anorectal } \\
\text { anomalies }\end{array}$ \\
\hline $1 \mu \mathrm{M}$ iloprost & $+7 \cdot 0(2 \cdot 5)$ & $+7 \cdot 4(4 \cdot 5)$ \\
$9 \mu \mathrm{M}$ acetylcholine & $(\mathrm{n}=3)$ & $(\mathrm{n}=3)$ \\
$50 \mathrm{MU} / \mathrm{ml}$ STa enterotoxin & $+24 \cdot 9(9 \cdot 7)$ & $+70 \cdot 9(27 \cdot 9)$ \\
& $(\mathrm{n}=4)$ & $(\mathrm{n}=5)$ \\
& $+64 \cdot 1(18 \cdot 1)$ & $+88 \cdot 7(26 \cdot 7)$ \\
& $(\mathrm{n}=5)$ & $(\mathrm{n}=5)$ \\
\hline
\end{tabular}

Results are given as mean (SEM). $\mathrm{n}=$ number or children. Other abbreviations as in Table I. No significant difference exists between the response of the two groups of tissues.

range 3 to 72). The basal values were similar between the two groups of children and were not significantly different from the values obtained for the rectosigmoid colon. All tissues were ganglionic.

The response to neurally mediated secretion with iloprost $\left(10^{-6} \mathrm{M}\right)$, serosal acetylcholine $(9 \mu \mathrm{M})$, and mucosal STa enterotoxin (50 MU/ $\mathrm{ml}$ ) were similar between tissues from children with Hirschsprung's disease and the controls (Table II) and were similar to those of the ganglionic rectosigmoid colon.

These data show that the secretory response of aganglionic colon to certain neurotransmitters including acetylcholine is impaired and this abnormality extends beyond the level of the aganglionosis. The secretion in response to other secretagagues acting directly on the colonocyte, however, is unaffected by the abnormal innervation.

\section{Discussion}

This is the first report giving details of the basal electrical values in paediatric rectosigmoid and transverse colon. Segmental heterogeneity, principally reflecting $\mathrm{Na}^{+}$transport, exists between the proximal and distal colon both in the rat and human colon. ${ }^{10-13}$ Consequently, we have considered the transverse and rectosigmoid separately. The basal electrical values in the rectosigmoid and transverse colon were similar and both were comparable with the reported data on adult colon ${ }^{10-21}$ although we have not identified the ions participating in either the basal or secretory responses.

Studies in animal and human colon show that certain developmental changes in enterocyte tissue enzymes occur in the colon, particularly in the immediate pre and postnatal period. ${ }^{22}$ Jenkins et $a$, $^{2324}$ using in vivo rectal dialysis, found evidence of fully developed sodium transport in preterm neonates but reduced anion exchange (probably reflecting net bicarbonate secretion) in children of 1 to 12 months of age. We found no significant correlation between the basal potential difference and age. Basal potential difference readings obtained in Ussing chamber preparations of human colon primarily reflect active sodium transport. ${ }^{112}$ Assuming this is similar in infant colon, the data presented here support the in vivo data that human electrogenic sodium transport is fully developed at birth.

Basal electrical properties of rat distal colon have a considerable neural tone as shown by the fall in the potential difference and short circuit current to tetrodotoxin. ${ }^{25}$ We hypothesised that a changed response to secretory stimuli might exist in $\mathrm{HD}$ as a result of the changes in the innervation to the colon and that these changes would be reflected in the electrical indices. The similar basal electrical indices in ganglionic and aganglionic tissues show that basal electrogenic ion transport in infants is not influenced by the enteric nervous system in either normally innervated or aganglionic colon - that is, HD - and highlight an important difference between the neural control of rat and human colonic ion transport. No significant difference was found in the response of aganglionic and ganglionic colon to STa enterotoxin in the presence or absence of tetrodotoxin. The neural influences might act on electrically silent ion transport mechanisms such as bicarbonate secretion but these were not examined in this study.

In this study, the reduced or absent response to acetylcholine but not carbachol in aganglionic rectosigmoid colon might result, at least in part, from reduced concentrations of acetylcholine reaching the basolateral muscarinic receptors through the enzymatic breakdown by the abundant tissue acetylcholinesterase activity. Studies on non-epithelial tissues have shown increases in muscarinic receptor density in response to reduced exposure to acetylcholine. ${ }^{26}$ Although we have not examined muscarinic receptor density, the variability in the response to carbachol suggest that changes in muscarinic receptor density or activation, or both may also occur in aganglionic colon.

The reduced response of the proximal ganglionic colon in the children with HD to $9 \mu \mathrm{M}$ acetylcholine has important implications for the siting of the surgical anastomosis of the proximal ganglionic colon. It is possible that these tissues are from the 'transitional zone' (the border between aganglionic and ganglionic tissue) although the histological acetylcholinesterase activity was not distinguishable from control ganglionic colon. The functional assay used here is, therefore, of greater sensitivity than acetylcholinesterase staining. These findings show that the normality of the proximal bowel cannot be adequately assessed by acetylcholinesterase activity and the presence of ganglion cells.

The time during which the major vascular supply was occluded varied between tissues and cannot be corrected for. A reduced viability of the aganglionic colon could account for the reduced responses to the iloprost and acetylcholine. This was considered unlikely, however, for the following reasons: the basal values and response to IBMX and STa enterotoxin were comparable with control tissues and with the proximal ganglionic tissue from HD. The gang lionic rectosigmoid colon also responded to iloprost comparable with the control tissues and so acted as an internal control.

In conclusion, the in vitro electrical properties of paediatric transverse and rectosigmoid colon are reported. The results indicate that (a) the electrogenic ion transport mechanisms in both the rectosigmoid and proximal transverse colon of children are similar, and (b) comparable with reported adult data; (c) basal net electrogenic ion transport of the transverse and rectosigmoid 
colon are unaffected by the neural abnormalities in the colon in HD; (d) aganglionic and ganglionic colon from children with HD are able to respond to certain secretagogues that act directly on the colonocyte, and (e) this response does not have a neural component; ( $f$ ) the response of aganglionic rectosigmoid colon to neurally mediated secretion through acetylcholine and iloprost is impaired; (g) the proximal ganglionic rectosigmoid colon in children with $\mathrm{HD}$ also exhibits an attenuated response to acetylcholine despite normal histology. These findings show that the neural abnormalities in HD exert an inhibitory effect on the secretory mechanisms in response to cholinergic stimuli. The problems of constipation seen in children with HD are due not only to abnormal smooth muscle and sphincter function but to a reduced secretory potential of the rectosigmoid colon.

The authors wish to thank the consultant surgeons, Mr D Drake, Mr R Brereton, and Mr E Kiely, Hospitals for Sick Children, London, for their collaboration and Mr M Daley, Department of Biomedical Engineering for making the Ussing chambers. This work was supported by Action Research.

1 Holschneider AM. Hirschsprung's disease. Stuttgart: Hippokrates-Verlag, 1982.

2 Heath $\mathrm{AL}$, Milla PJ, Spitz L. The absorptive function of colonic aganglionic intestine: are the Duhamel and Martin colonic aganglionic intestine: are the Duhamel and
procedures rational? $\mathcal{F}$ Pediatr Surg 1985; 20: 34-6.

3 Hardy SP. Electrogenic colonic ion transport in human Hirschsprung's disease f Physiol 1992; 452: 352P.

4 Naftalin RJ, Smith PM. A microprocessor-based device for the control and measurement of short-circuit current across small intestine. $\mathcal{F}$ Physiol 1984; 348: $13 \mathrm{P}$.

5 Hoyle CHV, Burnstock G. Neuronal populations in the submucous plexus of the human colon. 7 Anat 1989; 166: 7-22.

6 Karnovsky MJ, Roots L. A 'direct-coloring' thiocholine method for cholinesterases. F Histochem Cytochem 1964; 12: 219-21.

7 Diener M, Bridges RJ, Knobloch SF, Rummel W. Neuronally mediated and direct effect of prostaglandins on ion transport in rat colon descendens. Naunyn Schmiedeberg's Arch in rat colon descendens.

8 Cohen MB, Guarino A, Shukla R, Giannella RA. Age-related differences in receptors for Echerichia coli heat-stable enterotoxin in the small and large intestine of children. Gastroenterology 1988; 94: 367-73.

9 Huott PA, Liu W, McRoberts JA, Gianella RA, Dharmsathaphorn K. Mechanism of action of Escherichia coli heat stable enterotoxin in a human colonic cell line. 7 Clin Invest 1988; 82:514-23.

10 Hubel KA, Renquist K, Shirazi S. Ion transport in human cecum, transverse colon and sigmoid colon in vitro. Gastrocecum, transverse colon and

11 Sandle GI, Wills NK, Alles W, Binder HJ. Electrophysiology of the humam colon: evidence of segmental heterogeneity Gut 1986, 27: 999-1005.

12 Sandle GI, McGlone F. Segmental variability of membrane conductances in rat and human colonic epithelia: implications for $\mathrm{Na}, \mathrm{K}$ and $\mathrm{Cl}$ transport. Pflugers Arch 1987; 410 173-80.

13 Sandle GI, McGlone F. Segmental heterogeneity of basal and aldosterone-induced electrogenic $\mathrm{Na}$ transport in human colon. Pflugers Arch 1989; 414: 706-12.

14 Sellin JH, DeSoigne R. Ion transport in human colon in vitro. Gastroenterology 1987; 93: 441-8.

15 Grady GF, Duhamel RC, Moore EW. Active transport of sodium by human colon in vitro. Gastroenterology 1970; 59: 583-8.

16 Escobar E, Galindo F, Parisi M. Water handling in the human distal colon in vitro: role of $\mathrm{Na}, \mathrm{Cl}$ and $\mathrm{HCO}_{3}$. Biochim distal colon in vitro: role of $\mathrm{Na}$

17 Hawker PC, Mashiter KE, Turnberg LA. Mechanisms of transport of $\mathrm{Na}, \mathrm{Cl}$ and $\mathrm{K}$ in the human colon. Gastroenterology 1978; 74: 1241-7.

18 Kuwahara A, Cooke HJ, Carey HV, Mekhjian H, Ellison EC McGregor B. Effects of enteric neural stimulation on chloride transport in human left colon in vitro. Dig Dis $\mathrm{Sc}$ 1989; 34: 206-13.

19 Rask-Masden J, Hjelt K. Effect of amiloride on electrical activity and electrolyte transport in human colon. Scand $\mathcal{F}$ Gastroenterol 1977; 12: 1-6.

20 Sandle GI, Higgs N, Crowe P, Marsh MN, Venkatesan S Peters TJ. Cellular basis for defective electrolyte transport in

21 Willis NK, Alles WP, Sandle GI, Binder HJ. Apical membrane properties and amiloride binding kinetics of the brane properties and amiloride binding kinetics of the
human descending colon. Am $\mathcal{f}$ Physiol 1984; 247: G749-57.

22 Potter GD. Development of colonic function. In: Lebenthal E Potter GD. Development of colonic function. In: Lebenthal E,
ed. Human gastrointestinal development. New York: Raven Press, 1989: 545-58.

23 Jenkins HR, Milla PJ. The development of colonic transpor mechanisms in early life: evidence for reduced anion exchange. Early Hum Dev 1988; 16: 213-8.

24 Jenkins HR, Fenton TR, McIntosh N, Dillon MJ, Milla PJ Development of colonic sodium transport in early childhood and its regulation by aldosterone. Gut 1990; 31: 194-7.

25 Andres H, Bock R, Bridges RJ, Rummel W, Schreiner J Submucosal plexus and electrolyte transport across rat colonic mucosa. F Physiol 1985; 364: 301-12.

26 Nathanson NM. Regulation and development of muscarinic receptor number and function. In: Brown JH, ed The muscarinic receptors. Clifton, New Jersey: Humana Press, 1989: 419-54. 